\title{
Evaluation of toxic effects of two weight reduction pills
}

$$
\text { تقييم التأثيرات السمية لنوعين من حبوب انقاص الوزن }
$$

Maha F. Al-Taee Hadeel Waleed Abdul-Malek Laheeb Jamal Majeed

College of Science/ Baghdad University

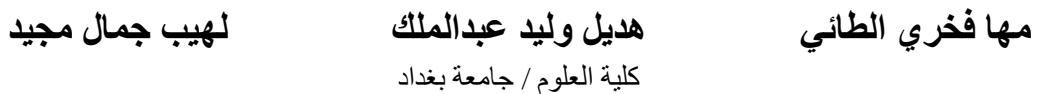

\section{Abstract}

This study involved evaluation of side effects of two weight reduction pills that had been widely distributed in the last period. Two weight reduction compounds are studied, Reductil (containing chemical substances) and Chinese's weight reduction herbs (containing natural substances). Two doses for each compound are used in this research; $5 \mathrm{mg} / \mathrm{ml}$ and $0.5 \mathrm{mg} / \mathrm{ml}$ for Reductil, while $30 \mathrm{mg} / \mathrm{ml}$ and $10 \mathrm{mg} / \mathrm{ml}$ for Chinese weight reduction herbs. To evaluate the toxic effects of these compounds, the following parameters were determined which include mitotic index (cytogenetic analysis), serum FSH and LH hormones level (follicles stimulation hormone/FSH and lutenising hormone/LH) and histological examination of female mice ovaries. Control group were treated with PBS for comparison. Results revealed that both compounds showed significant changes with the all studied parameters and at both doses when compared with control and, Reductil was shown to be more toxic than the Chinese herbs.

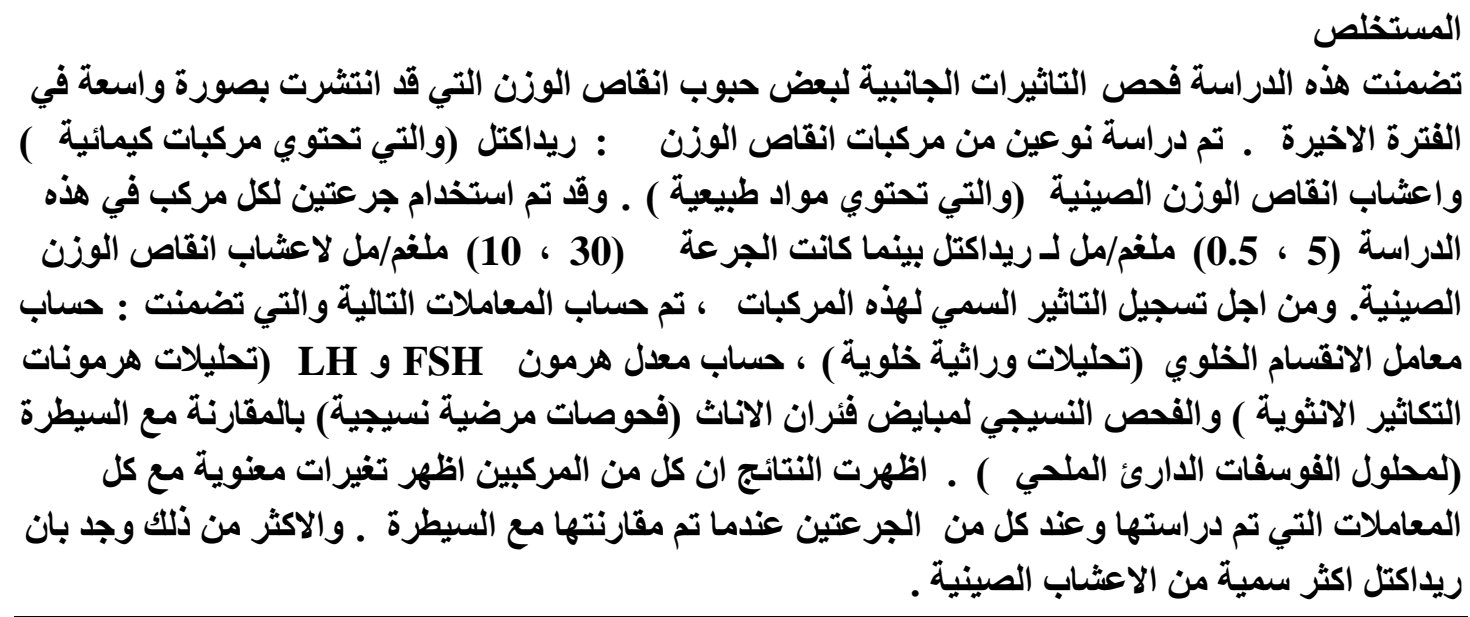

\section{Introduction}

Obesity is a disease characterized by an excess body fat. A number of concomitant pathological processes and diseases are associated with obesity including coronary heart disease, hypertension, stroke, non-insulin dependent diabetes mellitus and certain forms of cancer. Besides changes in diet, behavior and physical activities, obesity may be treated by surgery or pharmacological therapy. Thus, many weight reduction pills are developed in the markets to solve the problem of obesity, but most of them were shown to cause adverse side effects after a period of their use. One of these pills is Reductil and Chinese weight reduction herbs [1]. 
Chinese pills prepared for natural herbs, which are composed of roots, bark, flowers, seeds, fruits, leaves, and branches, and although these herbs were processed to reduce any possible side effects by detoxifying them, some remain having toxic substances that would not act unless after their use [2]. The Food and Drug Administration had warned people to avoid Chinese diet pills because they may contain a drug banned for causing dangerous side effects. The Chinese pills were among several linked to hundreds of illnesses and several deaths in Asian countries [3]. Reductil contains the active ingredient (sibutramine hydrochloride), and it is used to treat very overweight (obese) patients, who have not been able to lose weight using a low calorie diet and exercise. It works by altering the level of two chemicals in the brain, serotonin and noradrenaline, which help regulate energy intake and output. Each Reductil capsule contains the following substances: lactose, cellulose-microcrystalline, silica colloidal anhydrous. Magnesium stearate, gelatine, titanium dioxide. Shellac, ecithin, dimethicone, sodium lauryl sulphate, propylene glycol, indigo carmine CI73015, iron oxide black CI77499 and quinoline yellow CI47005 [4]. However, also several side effects and precaution from using reductil had been also recorded after it is use by many obese patients, in which it was shown to posses' toxic substances [5].

This study aims to evaluate the toxic effects of two types of weight losing pills.

\section{Materials and methods}

All the chemicals were obtained from Sigma Chemical Co. (USA) and BDH (England).

Experimental Animals: Five groups of female albino Swiss BALB/c mice (with five mice in each group) were obtained from the Biotechnology Research Center/ ALNahrain University, were used in this study. Their ages were ranged between (8-12) weeks and weighting (25-30) gm. They were divided into subgroups, and each group was placed in a separate plastic cage. The cages were kept in a room with $(23-25) \mathrm{C}^{\mathbf{o}}$ temperature. The animals were fed with a suitable quantity of water and complete diet.

\section{Animal preparation and drug treatment:}

The first and second groups of mice were given orally low $0.5 \mathrm{mg} / \mathrm{kg}$ and high $5 \mathrm{mg} / \mathrm{kg}$ doses of Reductil, respectively. While, the third and the fourth groups of mice were given orally low $10 \mathrm{mg} / \mathrm{kg}$ and high $30 \mathrm{mg} / \mathrm{kg}$ doses of Chine's herbs, respectively. The remaining group of mice received (PBS) alone as a control. The animals were treated for two successive weeks and then killed. Determination of mitotic index, reproductive hormones (FSH, LH) and histopathological examination of ovaries were done for both treated and not treated female mice.

\section{Chromosomal preparation from somatic cells of the mouse bone marrow:}

This method was done according to [6]. Each animal was injected (I.P) with $0.25 \mathrm{ml}$ colchicine with a concentration of $(1 \mathrm{mg} / \mathrm{ml}) 2 \mathrm{hr}$ before sacrificing the animal, Then the animal was sacrificed by cervical dislocation and fixed on supine position on the anatomy plate and the abdominal side of the animal and its thigh region were swabbed with $70 \%$ ethanol. The femur bone was dissected, cleaned from the surrounding tissues, and gapped from the middle with a forceps in a vertical position over the edge of test tube. By sterile syringe $5 \mathrm{ml}$ of PBS were used to wash and drop the bone 
marrow in the test tube. The latter was centrifuged at speed of $2000 \mathrm{rpm}$ for $10 \mathrm{~min}$. The supernatant was removed and $5 \mathrm{ml}$ of potassium chloride $0.075 \mathrm{M}$ was added as a hypotonic solution, then the test tubes was left for $30 \mathrm{~min}$ in water bath at $37 \mathrm{C}^{\circ}$ and shaked from time to time. The tube was centrifuged at $2000 \mathrm{rpm}$ for $10 \mathrm{~min}$, the supernatant was removed and the fixative solution was added (as drops) on the inside wall of the test tube with the continuous shaking, the volume was fixed to $5 \mathrm{ml}$. The tube was kept at $4 \mathrm{C}^{\circ}$ for $30 \mathrm{~min}$ to fix the cells, and then centrifuged at $2000 \mathrm{rpm}$ for $10 \mathrm{~min}$. The process was repeated three times and the cells were suspended in $2 \mathrm{ml}$ of the fixative solution. By a pasture pipette, few drops from the tube were dropped vertically on the chilled slides from a height of 3 feet at a rate of (4-5) drops to give the chance for the chromosomes to spread well. Later the slides were kept to dry at room temperature, and then stained with Giemsa stain and left for 15min and washed with D.W.

\section{Assay measurements of hormones:}

Serum hormones (FSH, LH) concentrations were evaluated with a Bio merieux Italia S.P. a vidia campigliano, 58 50015-point A EMA $\left(\mathrm{F}_{1}\right)$ Italia miniVIDAS, following the manufacturer's recommendations.

Histological Examinations: This was performed according to [7]. After scarifying the animal, ovaries were taken for histopathological examination, then placed in Bouin fluid overnight, and processed for routine paraffin embedding. Three serial sections per ovaries (5- $\mu \mathrm{m}$ thick) were cut and mounted on slides, deparaffinized, rehydrated, and stained with hematoxyline - eosin stain.

Statistical Evaluation: Data were analyzed by 1-way analysis of variance with ANOVA- test. Data are presented as means \pm SE. The level of significance was $\mathrm{P}<$ .05. [8].

\section{Results and discussion}

It is important to know the side effects of weight reduction pills. Diet pills that inhibit absorption of fats are gastrointestinal side effects, causes increased defecation, fecal incontinence, abdominal pain, nausea, infectious diarrhea, and rectal pain. Other pills work by epinephrine, serotonin, and dopamine reuptake inhibition. One of these diet pill side effects is that it is known to substantially increase blood pressure in some patients, back pain, abdominal pain, hypertension, palpitation, anorexia, constipation, nausea, thirst, joint disorder, insomnia, dizziness, anxiety, depression, and rash [9].

In this study some of the toxic effects of two weight reduction pills were studied evaluating by some parameters. One of these parameters is; the determination of the mitotic index (MI) of the MI of B.M. cells. Results revealed that both pills show significant decrease in the percentage of $\mathrm{MI}$ and at both doses when compared with control $49.21 \%$ as shown in Table (1). The MI reached to (38.97 and 30.76) \% after treatment with Reductil with (5 and 0.5$) \mathrm{mg} / \mathrm{ml}$ respectively, while it was (41.44 and $36.02) \%$ after treatment with Chinese weight reduction herbs at (30 and 10) $\mathrm{mg} / \mathrm{ml}$ respectively. However, from leaflet of these two pills, Chinese weight reduction pills contain only beneficial herbs and little fruits, while Reductil contain chemical compounds that also not harmful. But in fact both of them were shown to be toxic. The genotoxicity of them had also been investigated by some authors $[10,11]$. 
Table (1): Cytogenetic effects of weight reduction pills in comparison with control on mouse bone marrow cell.

\begin{tabular}{cc} 
Groups & $\begin{array}{c}\text { Mitotic index } \\
(\text { mean } \pm \text { SE) }\end{array}$ \\
Control (PBS) & A \\
& $49.21 \pm 1.19$ \\
B & $41.44 \pm 0.83$ \\
Chinese weight reduction herbs $30 \mathrm{mg} / \mathrm{ml}$ & $\mathrm{C}$ \\
Chinese weight reduction herbs $10 \mathrm{mg} / \mathrm{ml}$ & $36.02 \pm 1.37$ \\
Reductil $5 \mathrm{mg} / \mathrm{ml}$ & $\mathrm{C}$ \\
& $38.97 \pm 1.55$ \\
Reductil $0.5 \mathrm{mg} / \mathrm{ml}$ & $\mathrm{D}$ \\
\hline
\end{tabular}

Differences A, B, C, D are significant to comparison rows. ( $\mathbf{p}<0.05)$

More over the toxic effect of these weight losing pills are examined by determining the level of two fertility hormones (FSH and LH) as shown in Table (2). After treatment of female mice, serum was collected and levels of these hormones were determined. The level of FSH after treatment with Reductil at both doses was reduced significantly to $(0.21,0.14) \mathrm{mIu} / \mathrm{m}$ respectively, while its level decrease significantly to $(0.25,0.19) \mathrm{mIu} / \mathrm{m}$ repectively after treatment with the both doses of Chinese pills when compared with control $0.33 \mathrm{mIu} / \mathrm{m}$.

The level of LH hormone was also decreased significantly when compared with control $0.45 \mathrm{mIu} / \mathrm{m}$ after treatment with the two doses of reductil, which were $(0.37$, $0.29) \mathrm{mIu} / \mathrm{m}$, while it reached to $(0.33,0.24) \mathrm{mIu} / \mathrm{m}$ respectively, after treatment with the two doses of Chinese pills.

Table (2): Fertility activity of weight reduction pills in comparison with control in mice.

\begin{tabular}{|c|c|c|}
\hline Groups & FSH mIu/m $($ mean \pm SE) & LH mIu/m (mean \pm SE) \\
\hline Control & $\mathbf{A}$ & $\mathbf{A}$ \\
\hline PBS & $0.33 \pm 0.66$ & $0.45 \pm 1.03$ \\
\hline Chinese weight reduction herbs & AB & B \\
\hline $30 \mathrm{mg} / \mathrm{ml}$ & $0.25 \pm 1.35$ & $0.37 \pm 0.89$ \\
\hline Chinese weight reduction herbs & C & C \\
\hline $10 \mathrm{mg} / \mathrm{ml}$ & $0.19 \pm 1.09$ & $0.29 \pm 1.22$ \\
\hline Reductil & C & D \\
\hline $5 \mathrm{mg} / \mathrm{ml}$ & $0.21 \pm 143$ & $0.33 \pm 1.36$ \\
\hline Reductil & D & $\mathbf{E}$ \\
\hline $0.5 \mathrm{mg} / \mathrm{ml}$ & $0.14 \pm 0.76$ & $0.24 \pm 097$ \\
\hline
\end{tabular}

Differences A, B, C, D are significant to comparison rows.

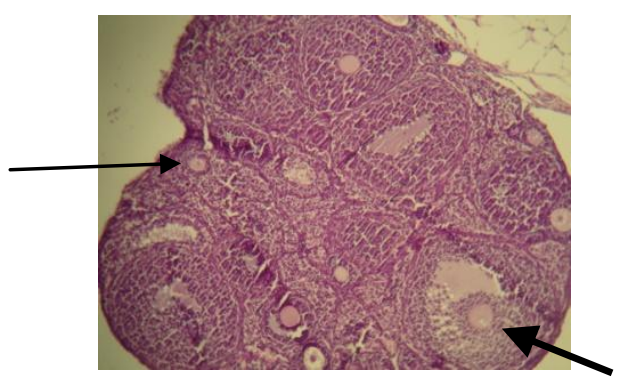

Figure (1): ovary sections showing different maturation of follicles (primary $(\rightarrow$ ) and growing follicle $(\rightarrow))$ H\&E (100X). 
However, up to our knowledge, no available studies about the effect of these pills on hormone levels, although many works on the patients who suffering from weight losing pills side effects $[12,13]$, but still there is no proved results, and thus, this research may be one of the first studies in this field. In fact these results have been more proved by the histological examination results.

An important requirement in toxicological experiments is the ability to assess the effects of compounds on specific organs. This is done through macroscopic and histopathological examination of the tissue. In this study the studied organ was the ovaries as shown in figures.

Figure $(1,2)$ show the effect of Reductil at both of $(5,0.5) \mathrm{mg} / \mathrm{ml}$ respectively. Results showed that Reductil cause histopathological changes at both doses. In Figure (1), section of ovary of treated animal showed different maturation of follicles (primary and growing follicle), while in Figure (2), section of ovary in treated groups showed more growing follicle.

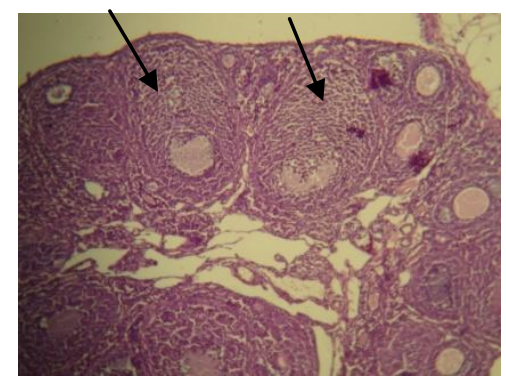

Figure (2): ovary sections showing a prominent maturation of the gravian follicles to secondary follicles ( $\longrightarrow$ ) H\&E (100X).

While, in Figure $(3,4)$ the effect of Chinese pills on the treated mice ovaries after treatment with $(30,10) \mathrm{mg} / \mathrm{ml}$ respectively were shown. Results in Figure (3) reveled significant changes in the treated ovaries (section of ovary in the treated animal showed different stages of maturation of follicle (primary more than secondary with few corpus luteum, while, no significant changes in the appearance of primary follicle than secondary in Figure (4) after treatment with lower dose of Chinese pills . Moreover, as we see form the results that Reductil had caused more significant changes than the Chinese weight reduction herbs. One explanation for this, is that Reductil consist of chemical substances while the Chinese herbs are consist from natural substances or it required more time to express their effect than Reductil.

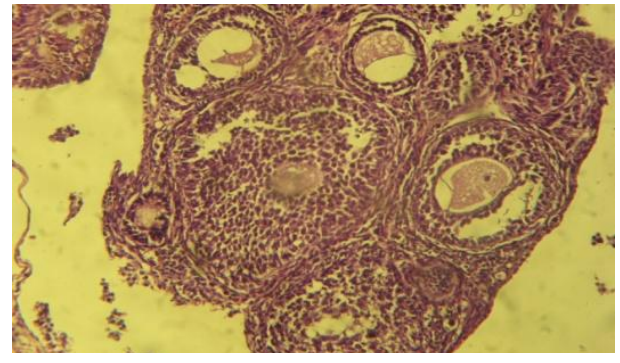

Figure (3): ovary sections showing different stages of maturation of follicle (primary more than secondary with few corpus luteum H\&E (40X).

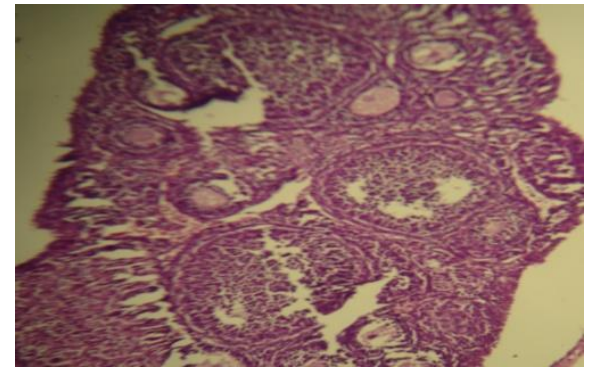

Figure (4): ovary sections showing no significant effects $H \& E$ (100X). 


\section{References}

1. Samuel, K. (2004). Long-Term Pharmacotherapy for Obesity. Obesity Research. 12: $166 \mathrm{~s}-163 \mathrm{~s}$.

2. Richard, B. (1996). Adverse events involving certain Chinese herbal medicine and the response of the profession. J. Chinese Med. 50:12-22.

3. Lisa, T. C. (2002). Asia's Killer Diet Pills. www.Time.com

4. Roberto, V. (2005). Effect of sibutramine on weight management and metabolic control in type 2 diabetes. Diabetes Care. 28(4): 942-949.

5. Des, C. (2009). Reductil. Pharmacist. 5(11): 2-4.

6. Allen, J. W.; Shuler, C. F.; Memnders, R. W. and Olatt, S. A. (1976). A simplified technique for in vivo analysis of sister chromatid exchange using 5bromodeoxyuridine tablets. Cytogen. Cell Genet. 18: 231-237.

7. Bancroft, J. D. and Stevens, A. S. (1992). Theory and Practice of Histological Techniques. $2^{\text {nd }}$ (ed.). Churchill Living Stone, Edinburgh, London. Pp:233-250.

8. Al-Mohammed, N. T.; Al-Rawi K. M.; Younis M. A. and Al-Morani W. K. (1986). Principle of Statistics. J. Al-Mousl University.(2):33-67.

9. Jacksonville, F. L. (2007). Popping a Pill Is Not Going to Get the Weight Off. www.prweb.com.

10. Cristiano, J. S. (2010). An evaluation of the genotoxic and cytotoxic effects of the anti-obesity drugs sibutramine and fenproporex. Hum Exp Toxicol. 29(3): 187-197.

11. Joëlle, L.; Nortier, M.; Marie, C.; Muniz M.; and Heinz, H. (2000). Urothelial Carcinoma Associated with the Use of a Chinese Herb. N Engl J Med 2000; 342:1686-1692.

12. De Smet, P. A. (2004). Health risks of herbal remedies. Clin Pharmacol Ther., 76(1):1-17.

13. June, R. (2010). Top obesity drug sibutramine being suspended. www.news.bbc.co.uk 